\title{
Modified Reverse Salam Product as an Innovative alternative for mobilizing fixed deposits in Jurisdictions with Limited Sharia Compliant Investment Avenues to Promote Financial Inclusion
}

\begin{abstract}
Aishath Muneeza
Abstract. With the fintech (financial technology) solutions available in the market today, innovative ways to provide financial inclusion is needed. However, the most critical challenge in the arena is the limited availability of shariacompliant investment avenues in some of the jurisdictions of the world where Islamic banking and finance has not yet fully taken off. The main objective of this research is to introduce a universally accepted mechanism using salam, one of the least used Islamic finance contracts in Islamic commercial banking for mobilizing fixed deposits. This will be ideal to be used in jurisdictions with limited sharia-compliant avenues. This is exploratory legal research that aims to provide an adequate and effective product for the jurisdictions that aspires to have a sophisticated fixed return guaranteed investment products structured in a sharia-compliant manner. Simultaneously, the proposed product in this research will serve the less privileged community of the society whose commodities can be used as an underlying asset in structuring the product. However, this social impact of the product will differ depending on the jurisdiction in which it is applied and the decision of the financial institution in which the product is offered as it is there discretionary power to choose the underlying commodity used in the transaction. Fintech can also be fused with the suggested product, and as such, the product can be easily used by the population in physically remote locations in a convenient manner.
\end{abstract}

Keywords: deposit, financial inclusion, fintech, Islamic finance, salam, shariacompliance, sharia

\begin{abstract}
Abstrak. Keberadaan solusi fintech di pasaran saat ini memerlukan adanya inovasi-inovasi untuk mewujudkan keuangan inklusif. Akan tetapi, tantangan yang paling serius dalam hal ini adalah terbatasnya cara investasi yang sesuai dengan syariah di beberapa yurisdiksi di dunia, dimana perbankan dan keuangan syariah belum sepenuhnya diadopsi. Tujuan utama dari penelitian ini adalah memperkenalkan mekanisme yang diterima secara universal dengan menggunakan salam, sebagai salah satu jenis kontrak keuangan yang paling jarang digunakan dalam perbankan komersial syariah untuk memobilisasi deposito dengan pengembalian tetap. Hal ini dapat menjadi ideal digunakan dalam yurisdiksi yang memiliki kesusaian syariah terbatas. Studi ini merupakan penelitian hukum eksploratori yang bertujuan untuk menawarkan produk
\end{abstract}


yang tepat dan efektif bagi yurisdiksi yang berkeinginan untuk memiliki produk investasi terjamin dengan pengembalian tetap yang terstruktur dengan cara yang sesuai dengan syariah. Selain itu, produk yang ditawarkan ini akan dapat dimanfaatkan oleh komunitas yang kurang mampu dengan komoditas yang dapat digunakan sebagai asset dasar dalam penataan produk. Akan tetapi, dampak sosial dari produk ini akan berbeda-beda tergantung pada yuridiksi di mana ia diterapkan dan keputusan lembaga keuangan di mana produk tersebut ditawarkan. Hal ini karena adanya kekuatan diskresi untuk memilih komoditas dasar yang digunakan dalam transaksi. Fintech juga dapat digabungkan dengan produk salam, dan dengan demikian, produk tersebut dapat dengan mudah dimanfaatkan oleh populasi di lokasi-lokasi terpencil.

Kata kunci: deposit, financial inclusion, fintech, Islamic finance, salam, sharia-compliance, sharia

\section{Introduction}

Financial inclusion has become a critical challenge faced by the global islamic finance industry today. However, it is vital to point out that financial inclusion is not a unique to islamic finance industry per se, but it has been a challenge for the whole global finance industry irrespective of the geographical location and literacy rate of the society. The world has witnessed the introduction of fintech (financial technology) solutions to the finance industry, and it is hoped that this technological innovation will have a positive impact on financial inclusion.

It is reported in the 2014 Global Financial Inclusion (Global Findex) database that financial inclusion at a global level has been improved between 2011 to 2014. It was reported that $62 \%$ of adults globally have an account at a bank or another type of financial institution or with a mobile money provider. Between 2011 to 2014, 700 million adults became account holders, while the number of unbanked adults has reduced by $20 \%$.

In general, there are two types of financial exclusions. They are voluntary and involuntary. Voluntary financial exclusion is excluding from participating in the financial arena by his or her own will or choice. Involuntary financial exclusion is when a person excludes himself or herself from the financial landscape due to a reason that cannot be controlled by himself or herself. For example, due to a lack of accessibility in a geographical challenge area or any reason similar to this. Financial inclusion strategies need to be developed to resolve both of these financial exclusions and these strategies developed will differ according to the type and the target population bearing in mind the specific unique challenges faced in every jurisdiction. As such, it can be said that though financial inclusion is a universal 
challenge, the solutions to it are unique to every place as every place has a unique circumstance that needs to be understood and then only adequate and effective resolutions to the problems will be possible.

Islamic finance has accumulated assets worth more than USD 2 Trillion and is expected to surpass USD 3 Trillion by 2018. The initiatives to enhance financial inclusion via islamic finance has been taken by numerous governments and non-governmental agencies in the world today. The strategies used in these initiatives are different though the objectives of these initiatives are the same. Not only this, the implementation mechanisms and the tools used in these initiatives are also special. According to Bank Negara Malaysia Financial Sector Blueprint 2011-2020, the indicators proving the achievement of financial inclusion are effective usage of financial service by all citizens, convenient access to financial services and enhance the quality of financial services. The pillars of inclusion in islamic finance can be divided into two; that is risk-sharing/ assetlinked financing via Small-Medium Enterprises (SMEs), Microfinance (MF) \& micro-takaful; and redistribution institutions via zakat, sadaqahh, qard al-hasan and waqf.

The main objective of this research is to introduce a universally accepted mechanism using salam, one of the least used islamic finance contracts in islamic commercial banking for mobilising fixed deposits which will be ideal to be used in jurisdictions with limited sharia compliant avenues. This is exploratory legal research that aims to provide an adequate and effective product for the jurisdictions that aspires to have a sophisticated fixed return guaranteed investment products structured in a sharia-compliant manner. Simultaneously, the proposed product in this research will serve the less privileged community of the society whose commodities can be used as an underlying asset in structuring the product. However, this social impact of the product will differ depending on the jurisdiction in which it is applied and the decision of the financial institution in which the product is offered as it is there discretionary power to choose the underlying commodity used in the transaction. Fintech can also be fused with the suggested product, and as such, the product can be easily used by the population in physically remote locations in a convenient manner. It is anticipated that this research will assist the jurisdictions in the world with limited sharia compliant investment products to introduce a new product that will be adequate to fulfill the needs of the customers. 


\section{Jurisdictions with Limited Sharia Compliant Investment Avenues \& Financial Inclusion}

The appetite for islamic finance at a global level is growing, and each year a new jurisdiction in the world, irrespective of the faith conviction is adopting it. Islamic Finance News (IFN) Guide 2017 provides country reports for about 34 countries discussing the developments of islamic finance. The critical challenges in terms of the development of islamic finance are discussed in these jurisdictions, and one of the key issues highlighted is lack of availability of sharia-compliant investment avenues in some of the jurisdictions. Table A will provide a summary of the key challenges highlighted in the guide facing these countries.

Table 1. Summary of the key challenges faced by Jurisdictions in Development of Islamic Finance as per IFN Guide 2017

\begin{tabular}{|c|c|}
\hline Jurisdiction & Key Challenges \\
\hline Afganistan & $\begin{array}{l}\text { - Islamic finance is not practised via the formal banking system, mainly via qard } \\
\text { al-hasan, Mudärabah and musharakah. } \\
\text { - Around } 20 \% \text { of the Afghan population is banked while the remainder avoids this } \\
\text { facility due to the involvement of Riba. } \\
\text { - Currently, only seven out of } 17 \text { banks are offering Islamic banking services via the } \\
\text { window system and the services and products offered by these banks are limited } \\
\text { to Mudärabah, Murabaha, Musharakah and Ijärah. } \\
\text { - During 2016, most of the Islamic windows faced high liquidity, with the main reason } \\
\text { being the shortage of investment opportunities. Due to the involvement of Riba, } \\
\text { Islamic financial institutions are restricted from investment/placement opportunities } \\
\text { such as capital notes and overnight placement offered by the central bank. }\end{array}$ \\
\hline Australia & $\begin{array}{l}\text { - The favored asset class in Australia for Islamic investors is still real estate with } \\
\text { several commercial asset acquisitions in } 2016 \text {. }\end{array}$ \\
\hline Bahrain & $\begin{array}{l}\text { - The Bahrain Bourse had obtained the approval of the CBB regarding the Bahrain } \\
\text { Investment Market Rules. The new rules will create new landmarks in providing } \\
\text { additional financing alternatives to SMEs with a reasonable financing cost, as well } \\
\text { as providing more investment alternatives to investors. }\end{array}$ \\
\hline Bangladesh & $\begin{array}{l}\text { - In the case of financial inclusion, Islamic banks are doing better through their } \\
\text { small size deposit and investment products. } \\
\text { - In terms of asset quality, capital adequacy and profitability, Islamic banks are } \\
\text { outperforming their conventional peers. However, they still have scope to explore } \\
\text { further alternative banking products like mobile banking, internet banking and } \\
\text { e-commerce. }\end{array}$ \\
\hline Bosnia & $\begin{array}{l}\text { - Islamic finance public education projects are continuously implemented in } \\
\text { Bosnia through newspapers, radio and now even TV shows, sponsored by the } \\
\text { only Islamic Bank. }\end{array}$ \\
\hline
\end{tabular}




China $\quad$ Limited/no Islamic banking retail activities
- Opens up its cross-border capital movements and client needs in renminbi grow,
Standard Chartered Bank with its long 150-year history in China and presence
along with key renminbi offshore centers, is ideally placed to capitalize on the
B\&R initiative.
- Combined with Standard Chartered Saadiq, an established leader in Islamic
banking, with a presence in core Islamic markets and solid experience in cross-
border, project finance and capital markets,

France

- With nearly six million French Muslim citizens, France is one of the European countries with the biggest growth potential in terms of Islamic retail banking. French residents are more and more active in the Islamic finance market; for instance, some 'VIP-customers' working in the sport or media industries. Given this, various foreign Islamic banks are considering the establishment of a direct subsidiary in France, more particularly in the context of Brexit.

Hong Kong - Some local brokers have said that, although some government efforts existed during the past few years, a small Muslim population of 270,000 people and a lack of understanding of Islamic finance products in Hong Kong have contributed to the sluggish outcome.

- Nevertheless, the Hong Kong Monetary Authority has said that it is endeavoring to examine practical issues in order to formulate a Sukuk issuance plan that takes into consideration market conditions.

- Further, it would encourage corporates to consider issuing Sukuk, although it will depend very much on demand and pricing eventually.

India - The agricultural sector could benefit from Islamic finance, which would assist in pausing the cycle of debt and interest payments, which often regresses the progress of farmers.

- Lokmangal Cooperative Bank in Solapur, Maharashtra offers interest-free deposits and other similar products. The approach sought to be taken by the opening of this bank is essential to promote the financial inclusion of the masses and minority sectors. Reports suggest that the bank has so far managed to distribute INR250,000 (US\$3,690.91) to those financially in need. The bank is aiming to follow a 'participatory approach' model, where participation is being encouraged by the state government.

Indonesia - The challenge for Indonesia is now more on how to make other components of Islamic finance such as Islamic banking, corporate Sukuk, Islamic insurance and Islamic mutual funds more competitive and grow further.

- The government may need to encourage its state-owned enterprises to place more of their funding into Islamic banks and Islamic mutual funds.

- In Iran, all financial instruments should comply with sharia rules and regulations. Thus, it is unlawful in the financial system to trade in any conventional financial instruments or to establish any financial institution where its performance contradicts Islamic rules and regulations. 


\begin{tabular}{|c|c|}
\hline Italy & $\begin{array}{l}\text { In consideration of the growing Muslim community in Italy, which has now } \\
\text { reached some } 1.8 \text { million residents, and of the interest shown to the country } \\
\text { by Islamic investors, the possibility of setting up an Islamic bank has also been } \\
\text { discussed. This could happen in the form of a retail bank, providing bespoken } \\
\text { financing sharia-compliant banking products to the general public or in the form } \\
\text { of a commercial and investment bank, acting as a bridge between Middle East } \\
\text { investors and Italian SMEs. In particular, the bank could in the latter case, among } \\
\text { other things, advise Islamic investors in the purchase of controlling and minority } \\
\text { interests in Italian sharia compliant companies and businesses. }\end{array}$ \\
\hline
\end{tabular}

Japan - It is expected that major financial institutions will continue their efforts to include Islamic finance in their product suites in 2017. Japan is not a barren land of Islamic finance. It is expected to contribute significantly to the development of Islamic finance in the coming years, considering its unique nature in a global context of international finance. Although the volume of deals is not large and its presence in the market is not big, Japan will well to utilize the 'little head, great wit' strategy in Islamic financial markets.

Kenya A bank in Kenya, which offers sharia-compliant financing, was taken to court by
one of its borrowers over the nature of the facility that the borrower was granted.
The borrower alleged that the bank changed the facility that he was granted from
a fixed term financing to a revolving Musharakah financing which had the effect
of raising the interest rate from $18.5 \%$ to an Islamic profit-sharing equivalent of
19.5\%. This increased the borrower's payment obligations considerably. The bank
argued that the borrower was aware of the nature of the facility he was granted
and that the bank had explained the terms to the borrower on several occasions.
These instances show a lack of understanding of Islamic finance terminology and
documentation across the board. It also highlights that in some instances, Islamic
financing is expensive in Kenya compared to its conventional counterpart.

Kuwait

- The outlook for Kuwait's banking system in 2017 remains healthy due to the continued expectation of government spending as subdued oil prices linger. Supported by increasing demand for sharia-compliant financial products and facilities from wholesale and retail customers, the Islamic financial sector in Kuwait is regarded as an integral constituent of the country's path to development. Islamic banks in Kuwait hold approximately $45 \%$ of banking sector assets, according to data from the Central Bank of Kuwait (CBK).

- From a regulatory vantage point, the CBK has plans to enhance the local retail banking competitive environment by eliminating branch expansion restrictions on foreign banks which would grant them the ability to open branches in numerous locations, positioning them to compete directly against local institutions for a share of the retail banking market, especially considering that Kuwaiti banks are in parallel reducing their branch network to reduce costs.

Luxembourg - If Islamic finance promoters find a way to market sharia-compliant products as socially responsible Investments (SRIs), the industry can grow drastically.

Malaysia - To fuel the growth, the regulators are promoting the linkage between Islamic finance and sustainable responsible investing. This augurs well for the domestic Sukuk market's thrust into its next phase of development and, ultimately, its sustainability as a competitive product amid the mainstream financial markets. 


\begin{tabular}{ll}
\hline Maldives & In the year 2017, it is anticipated that the largest bank in the country, the Bank \\
& of Maldives, will start offering Islamic financing products that will help the \\
population in other islands to use Islamic finance since accessibility is the most \\
critical issue.
\end{tabular}

New Zealand - From an Islamic finance perspective, Awqaf NZ commissioned a Sukuk Waqf study in partnership with the International Shari'ah Research Academy for Islamic Finance of Malaysia. A sharia-compliant retirement savings fund called Amānah Ethical launched a couple of years ago is gaining momentum in the New Zealand marketplace.

Nigeria - The decaying infrastructure and the needs of the current government, as well as dwindling oil revenues, made it necessary for the government to look for funds through the capital market.

Oman - Oman has, during 2016, achieved a sound infrastructure for its Islamic finance sector to develop and progress.

- Islamic finance has proven itself as an accepted and successful option for project financing in the private sector and as an alternative to conventional retail lending, and in both respects, it carries the potential for sustained growth into 2017.

Pakistan - Islamic finance has shown amazing growth over the past two decades. Strong demand for this segment has resulted in global financial assets surging.

- Growth in the Islamic banking sector continues to surpass that of conventional banks in several areas of banking and finance, supported by strong retail demand and positive legislation for the industry by the regulators.

- The Islamic banking industry in Pakistan, just like other jurisdictions elsewhere, faces some key challenges, including the limited availability of trained employees and a lack of understanding and awareness within the public. Despite its impressive growth, there is still a huge untapped market for the Islamic finance industry.

- Given its strong fundamentals and increasing public acceptability, the further growth prospects of Islamic finance in Pakistan are very promising. So far, the Islamic finance industry has not penetrated deep enough to serve the financial needs of SMEs, agriculture, microfinance and low-cost housing. Pakistan's massive infrastructure needs, especially those under the China-Pakistan Economic Corridor, represent lucrative Islamic finance public-private partnership opportunities in the high potential sectors of energy and construction. 


\begin{tabular}{ll}
\hline Qatar & The banking sector has maintained a strong performance overall. Overall net \\
profit for the banking sector increased by $1.4 \%$ for the last year, which was the \\
result of higher net interest/profit income by QAR4.3 billion (US $\$ 1.18$ billion) \\
and higher net fee and commission income by QAR962 million (US $\$ 263.93$ \\
million). However, share prices of the listed banks have had a turbulent year. \\
Islamic banks (both listed and non-listed) fell within that trend and despite \\
experiencing a rollercoaster year, maintained a strong performance.
\end{tabular}

Russia

- Russia historically does not have a visible Islamic finance industry, despite the fact that it has a significant (up to $10 \%$ ) Muslim population constituting a majority in nine Russian regions.

- However, over the years, there were attempts to either conduct particular Islamic finance transactions or establish retail practices. To a certain extent, these attempts have been successful, although the establishment of fully-fledged, comprehensive Islamic finance retail solutions is a matter for the coming years.

Saudi Arabia - Over the last few years, the Capital Market Authority (CMA) and the Saudi Arabian General Investment Authority have been focused on issuing new regulations and new products to help spur the domestic market and foreign investment into Saudi Arabia.

- The CMA also wants to encourage managers to develop products which can be accessed by the Saudi public to encourage individuals to invest their income in the Saudi domestic market.

Singapore - Increased awareness in Islam and Islamic finance among Malay Muslims: according to the Department of Statistics of Singapore, Malays make up 13.4\% of Singapore's population at the end of June 2016. Discussions with key players in Singapore's Halal industry such as MY Outlets have indicated that there is an increased awareness of the Halal concept among Malay Muslims with further enquiries into Islamic financing and how Islamic finance in Singapore can grow to serve the Malay Muslim community. Collaborations between Islamic financial institutions and key Malay Muslim organizations in Singapore are one of the ways to penetrate and increase the participation of Malay Muslims to grow Islamic finance in Singapore. The key for financial institutions offering Islamic finance to sustain the public's level of awareness and interest in Islamic finance and to identify the gaps which could be converted into opportunities once the economy recovers.

- Financial institutions need to identify the current gaps in the Singaporean market, where Islamic finance is not present. Products including Islamic credit cards, home financing and Takaful are only some of the areas which can be explored and developed further.

- It is important there is continuous engagement between Islamic financial institutions, regulators, the academic community and members of the public for secular nations such as Singapore to ensure the awareness and relevance of Islamic finance amid the current economic uncertainty.

South Africa - With the local economy under pressure, the South African Islamic finance industry has to adapt, innovate and evolve to continue on its growth trajectory.

- The market is looking for alternatives, but there is a need for education and awareness to highlight the value that Islamic finance provides.

- One of the major opportunities remains the expansion into the rest of sub-Saharan Africa, where the market is crying out for affordable, interest-free banking. 


\begin{tabular}{|c|c|}
\hline Tunisia & $\begin{array}{l}\text { - The Tunisian banking system consists of } 23 \text { full-service banks, of which five banks } \\
\text { are specialized (three Islamic banks, one SME finance bank and one microfinance } \\
\text { bank). } \\
\text { - Following certain major changes related to tax provisions (Finance Act 2014: the } \\
\text { exemption of profit margin from value-added tax and the avoidance of double } \\
\text { taxation on the transfer of properties) and those related to certain legal provisions } \\
\text { (Sukuk law, Islamic funds and Takaful), the New Banking Law approved in } \\
2016 \text { introduces a number of changes to the functioning and supervision of the } \\
\text { banking sector in order to reorganize it through the formal legal recognition of } \\
\text { Islamic banking activities. } \\
\text { This banking law defines Islamic finance transactions (Murabahah, Ijärah, } \\
\text { Mudärabah, Musharakah, Istisna', salam, Wadiah istithmar) and also allows all } \\
\text { banks to carry out Islamic finance transactions, subject to approval from the } \\
\text { central bank (including for Islamic windows). }\end{array}$ \\
\hline Turkey & $\begin{array}{l}\text { - Turkey has a massive role in the Islamic finance world by virtue of the fact } \\
\text { that it has issued a massive amount of Sukuk in recent years. Islamic finance } \\
\text { has a remarkable place in Turkey. Therefore, it is continuously developing and } \\
\text { expanding in the country. } \\
\text { - Even though new participation banks were established in 2016, the Turkish } \\
\text { government should pave the way for investors to increase the number of Islamic } \\
\text { banks since it has not reached a sufficient number. The government should } \\
\text { support and encourage the banking sector and make necessary amendments to } \\
\text { current regulations. }\end{array}$ \\
\hline UAE & $\begin{array}{l}\text { - The year } 2016 \text { was a year of slow and steady progress for Islamic finance in the } \\
\text { UAE. Although total banking assets under Islamic banks increased, the pace of } \\
\text { growth reduced in an otherwise challenging operating environment. } \\
\text { - Working toward its ambition to become the global capital of the Islamic } \\
\text { economy, the Dubai government announced plans to launch the world's first } \\
\text { sharia-compliant trade finance-focused bank in the UAE soon. The bank is to be } \\
\text { called the Emirates Trade Bank and will support endeavours to double the UAE's } \\
\text { estimated US } \$ 1.4 \text { trillion trade flows in } 2014 \text { by } 2020 \text {. }\end{array}$ \\
\hline UK & $\begin{array}{l}\text { - Islamic finance has developed rapidly in the UK over the past decade, and the UK } \\
\text { government has been very supportive of its development and promotion. The UK } \\
\text { hosted the first stand-alone Islamic financial institution in the EU and has the } \\
\text { highest value of sharia-compliant assets of any non-Muslim country. }\end{array}$ \\
\hline US & $\begin{array}{l}\text { - Foreign investors seeking Islamic finance products in the US continued to show } \\
\text { the greatest interest in private real estate investments in 2016, with relatively } \\
\text { marginal activity on US-originated Sukuk issuances or other sectors of Islamic } \\
\text { finance. } \\
\text { - US real estate valuations have been bolstered by strong fundamentals and a high } \\
\text { level of interest from a multitude of capital sources in 2016. Apart from the fact } \\
\text { that US real estate fits well with requirements of Islamic financial products, the } \\
\text { current strength and stability of the asset class make it the center of focus for } \\
\text { Islamic financial transactions in the US. }\end{array}$ \\
\hline
\end{tabular}

Source: Extracted from IFN Guide (2017) 
According to Pearce (2010), innovative financial inclusion means improving access to financial services for poor people via the safe and sound spread of new methods. The methods stated by Pearce (2010) is derived through experiences and lessons learned from policymakers throughout the world, especially leaders from developing countries. Nine broad principles of innovative financial inclusion have been stated by Pearce (2010) which are leadership, diversity, innovation, protection, empowerment, cooperation, knowledge, proportionality and framework. Each of these broad principles is explained in Table 2 .

Table 2. Principles of Innovative Financial Inclusion as described by Pearce (2010)

\begin{tabular}{|c|c|}
\hline Principle & Explanation \\
\hline Leadership & $\begin{array}{l}\text { Cultivate a broad-based government commitment to financial inclusion to } \\
\text { help alleviate poverty. }\end{array}$ \\
\hline Diversity & $\begin{array}{l}\text { Implement policy approaches that promote competition and provide market- } \\
\text { based incentives for the delivery of sustainable financial access and usage of } \\
\text { a broad range of affordable services (savings, credit, payments and transfers, } \\
\text { insurance) as well as a diversity of service providers. }\end{array}$ \\
\hline Innovation & $\begin{array}{l}\text { Promote technological and institutional innovation as a means to expand } \\
\text { financial system access and usage, including by addressing infrastructure } \\
\text { weaknesses. }\end{array}$ \\
\hline Protection & $\begin{array}{l}\text { Encourage a comprehensive approach to consumer protection that recognizes } \\
\text { the roles of government, providers and consumers. }\end{array}$ \\
\hline Empowerment & Develop financial literacy and financial capability. \\
\hline Cooperation & $\begin{array}{l}\text { Create an institutional environment with clear lines of accountability and } \\
\text { coordination within government; and also encourage partnerships and direct } \\
\text { consultation across government, business and other stakeholders. }\end{array}$ \\
\hline Knowledge & $\begin{array}{l}\text { Utilize improved data to make evidence-based policy, measure progress, and } \\
\text { consider an incremental "test and learn" approach acceptable to both regulator } \\
\text { and service provider. }\end{array}$ \\
\hline Proportionality & $\begin{array}{l}\text { Build policy and regulatory framework that is proportionate with the risks and } \\
\text { benefits involved in such innovative products and services and is based } \\
\text { on an understanding of the gaps and barriers in existing regulation. }\end{array}$ \\
\hline Framework & $\begin{array}{l}\text { Consider the following in the regulatory framework, reflecting international } \\
\text { standards, national circumstances and support for a competitive landscape: an } \\
\text { appropriate, flexible, risk-based Anti-Money Laundering and Combating the } \\
\text { Financing of Terrorism (AML/CFT) regime; conditions for the use of agents } \\
\text { as a customer interface; a clear regulatory regime for electronically stored } \\
\text { value; and market-based incentives to achieve the long-term goal of broad } \\
\text { interoperability and interconnection. }\end{array}$ \\
\hline
\end{tabular}


Banerjee, Abhijit and Newman (1993) and Galor and Zeira (1993) states that there can be negative effects of financial exclusion as it holds back investments and results in persistent income inequality, as it adds to negative incentives to save and work and incites repeated distribution in a society. Therefore, financial inclusion will lead to economic development.

As observed by Beck and Demirguc-Kunt (2008), financial inclusion gained global attention at the beginning of the $21^{\text {st }}$ century, when governments and central banks in developing nations began to focus on it. At the initial phase, financial inclusion was often viewed as the delivery of financial services to low-income segments of society at a reasonable cost and the financial inclusion in the economy is measured by the proportion of the population covered by commercial bank branches and ATMs, sizes of deposits and loans made by low-income households and SMEs. The disadvantages of caused using this way of measurement were that it did not take into account the voluntary financial exclusions. In contemporary times the concept of financial inclusion has evolved into main four dimensions: easy access to finance for all households and enterprises, sound institutions guided by prudential regulation and supervision, financial and institutional sustainability of financial institutions, and competition between service providers to bring alternatives to customers.

The focus of this research is to introduce an innovative product to the customers that will bring promote financial inclusion via Islamic finance. The product proposed in this research will provide an avenue to invest money in islamic banks for a fixed return in a sharia-compliant manner, and fintech solutions can enhance the reachability of the product.

\section{Modified Reverse Salam Product}

Modified reverse salam product is a newly proposed unique product by Mahaini (2017) for liquidity management purposes that can be introduced in the jurisdictions with limited sharia compliant investment avenues. The introduction of this product will facilitate and complement the global effort of financial inclusion in the sense that the product will provide an easy and a convenient way for islamic banks to mobilise funds from retail customers while providing a fixed return to the customers in a sharia-compliant manner. Simultaneously the banks have the liberty to fuse fintech to the product and the underlying commodity that will be traded in the transaction. If the bank opts to use agricultural commodities or commodities produced by poor and needy to structure the transaction, it will provide an opportunity to serve the social well-being of the population too. 
The Modified Reverse Salam product is structured using salam, an exceptional sale contract under islamic finance as the main transaction contract. Bay' salam is also known as bay' salaf as it was mentioned earlier (Umar, 1991). The permissibility of salam is an exceptional rule that prohibits the forward sale in sharia. In terms of defining salam, there are various definitions of it found from different islamic school of thoughts (Umar, 1991). Zaabi (2010) has described the various definitions of different schools of jurisprudence. Shafis define it as the selling of something that is specified and owed as they see it as a debt and hence do not make it a condition that the period (within which the sale object is to be delivered) be well-defined. The Hanbalis view salam as that which is handed over in exchange for something defined that is owed for a known period, and they believe that it is as a sale for a period, as the sale of an object bought and paid for in advance. They also see it as buying something postponed in exchange for something given in the moment, or as selling a time to come for the time now. Thus, it is a contract involving something that it is proper to sell, that is specified, that is owed; the delivery of it being postponed, in exchange for a price collected at the contract session. The condition attached here, namely that the price (the capital advanced) is handed over at the time of contract, avoids the prohibited transaction of one debt for another debt - money owed/promised in exchange for a thing owed/promised. The Mălikis define salam as the sale of something owed and specified by description in exchange for a price, the delivery of the thing being put off for a time they permit postponement of the transfer of the price to the buyer for a period of no more than three days as for them, the salam contract is simply an exchange or substitution contract stipulating binding obligation on the seller to be fulfilled by him by delivery of the sale object, not an equivalent for it nor for ready money.

According to Al-Zuhayli (2007), the following four conditions shall be present to make the salam contract valid.

1. Rabb al-salam or al-musalim: this is known as a forward buyer which can be an individual as well as a group or a company.

2. Al-Musalim ilyahi: the forward seller can also be an individual, group or a company. Majority of scholars state that the word salam or salaf must be mentioned in the offering statement.

3. Al-Musalim fihi: the object of forwarding sale. It is mandatory that the object of sale must be specified in term of genus, type, quantity and quality. All these must be agreed upon in unequivocal terms.

4. Ra's mal al-salam: price or capital sum of the forward sale. It is a paramount condition to determine the actual price clearly. It must be specified if it is measured in volume, weight or number. 
Not every commodity is suitable for a salam contract. It is usually applied only to fungible commodities. Some basic rules governing the salam is that the price should be paid in full at the time of the contract; goods whose quality or quantity cannot be determined by specification cannot be sold through the contract of salam. An example is precious stones; goods can be sold only by specifying the attributes, and they cannot be particularized to a given farm, factory or area; and the exact date and place of delivery must also be specified (Usmani, 2004).

Mahaini (2017) states that the first attempt to use the concept of reverse salam was made with the support of INCEIF in 2014 through research headed by Yousuf Saleem, whereby the author was a team member. The product was published in ISRA under the name: Reverse Salam As An Innovative Instrument For Investment Accounts. Mahaini (2017) explains that reverse salam does not refer to parallel salam or back to back salam in this context. However, the terminology used "Reverse Salam" is a concept in which the buyer of the commodity in normal case salam (bank) will be changed to customer and vice versa as it is a deposit product (Mahaini, 2017). In other words, the bank will be the seller, and the customer will be the buyer.

Figure 1. The structure of the first edition of Reverse Salam:
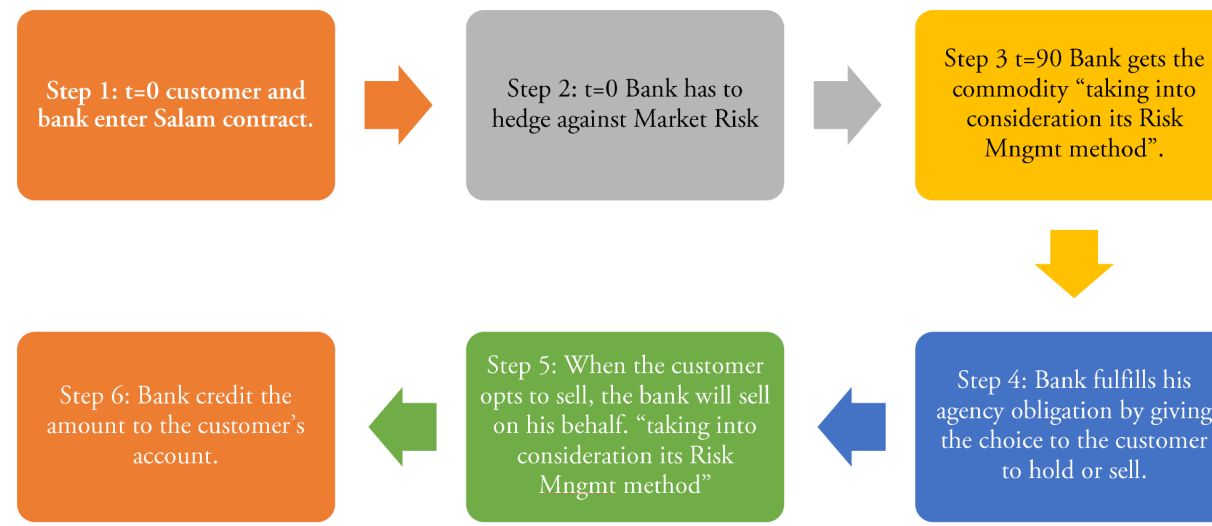

Step $3 t=90$ Bank gets the commodity "taking into consideration its Risk Mngmt method".

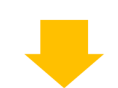

Step 5: When the customer opts to sell, the bank will sell on his behalf. "taking into consideration its Risk Mngmt method"

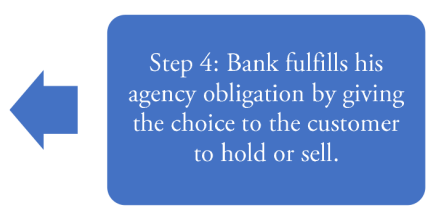

Source: Mahaini (2017)

According to Mahaini (2017), the disadvantages of the first version include among others two major issues: that is the sharia issues triggered with the use of Wakalah contract with salam contract when the bank is appointed as an agent to sell the commodity on behalf of the customer. The second issue arises due to the need to use hedging tools to mitigate market price fluctuation risk, which in turn has many concerns, including the controversial use of derivatives in sharia. 
Mahaini (2017) observes that the word "Modified" is used in a modified reverse salam product to distinguish it with the first edition mentioned hereinabove. The most significant change that this new model has is switching the underlying contract from a classical quantity based salam into a value-based Salam (Mahaini, 2017).

A value-based salam is a salam contract whereby the value rather than the quantity is determined upfront. The value determined by multiplying the quantity by the unit price. This allows the seller to mitigate price volatility over time (market risk). This concept is proposed to mitigate the market risk encountered in implementing salam contract at a practical level. For example, in Sudan salam contract was used in the field of agriculture, and though the contract has been implemented successfully, they have experienced the stress of the price variation (Dchieche \& Aboulaich, 2016).

From a sharia perspective, it is important to determine the validity of value-based salam, which plays a vital role in the successful implementation of the proposed product in this research. Based on the hadith of Prophet (SAW) which states that whoever enters into salaf (salam), should stipulate a determined weight and measurement, and a determined date of delivery, it is clear that it is mandatory to stipulate the price of the commodity with the quantity and quality delivered in the future date. Therefore in dealing with the concept of value-based salam, the question we need an answer from sharia perspective is whether the quantity of the commodity that could be delivered at the future date of which the price is determined and paid fully at the time of the salam contract can be determined at the time of the delivery of the commodity; which is at the future date. Al-Masri (2003) has illustrated this situation using the following example: "can I pay you now 100,000 dirhams on condition that you deliver me rice of a described quality after a year, the quantity of which would be determined on the date of delivery by dividing the capital (i.e. price of the rice) based on the market price of a kilogram of rice on the day of delivery, with a specific amount or percentage of discount from this price?" (Al-Masri, 2003, p.29).

Al-Masri (2003) states that though the majority of the scholars have held against the permissibility of value-based salam, some scholars such as Ibn Taymiyyah has made it permissible. He states that Ibn Taymiyyah says "Sale is permissible (...) at a price determined by the market, or at the price people sell at, which is one of two opinions in the Hanbali School of Islamic Jurisprudence" (cited in Al-Ikhtiyarat alFiqhiyyah, p.121 by Al-Masri, 2003, p.30). According to Al-Masri (2003), this view held by Ibn Taymiyyah is in relation to sale transactions in general, but as regards salam sale contracts specifically, Ibn Taymiyyah says "If he (the buyer) advances a 
specific amount of money against delivery (of a commodity) on a specific future date on condition that, on the date of delivery, he would purchase the commodity on the basis of a price less than that prevailing on the market by a specific amount, then the transaction would have been as valid as that of purchase at market price" (cited in Al-ikhtiyarat al-fiqhiyvah p.131 by Al-Masri, 2003, p.30). However, it is imperative to note here that Al-Masri (2003) has held that "I concur with Ibn Taymiyya's view that the market price of salam if it is meant to be the market price on the date of the contract, is valid. But if what is meant by it is the future market price on the date of delivery, it is not valid" (Al-Masri, 2003, p.31).

In contemporary writings, the concept of value-based salam is discussed and approved by Al Suwailem (2006) based on the view of Ibn Taymiyyah. According to Sami Al-Suwailem: (Ibn Taymiah has approved this form of salam, and his opinion was cited by Ibn Muflih, a prominent Hanbali scholar without objection (al-Rajhi)) (Al Suwailem, 2006). Other contemporary scholars have mentioned this contract, such as Kabir Hassan and Michael Mahlknecht, in their book: Islamic Capital Markets: Products and Strategies (Hassan \& Mahlknecht, 2011). According to Al Suwailem (2006), value-based salam is a form of salam where the price is defined as quantity times unit price. By referring to the views of Al Suwailem and Ibn Taimiyyah, Amina \& Rajae (2016) have also approved the use of value-based salam. Examples of value-based salam have been described by Omar, Abduh \& Sukmana (2012) as follows: The buyer of the commodity pays fully in advance for the salam contract to the seller. Assume that the agreed total price is US\$ 10,000 for oil. In the usual salam, the quantity of the oil, such as the number of the barrels to be delivered at the maturity, has to be agreed upon at the time when the salam contract was signed. In this value-based salam, instead of the quantity, the value is the thing that has to be determined up front. Value is the multiplication of the unit price per barrel times the quantity or number of barrels. For instance, both parties the buyer and seller, have reached an agreement of the salam contract in which one of the points is that at maturity the commodity is valued at as much as US\$11,000 and the buyer will have to pay only US\$10,000 for the commodity (oil). At maturity, the number of oil barrels will depend on the oil price at that point in time. Assuming the price of oil at maturity US\$50; thus the quantity of the oil that has to be delivered would be 220 barrels (US\$ 11,000 divided by US\$ 50) (Omar, Abduh \& Sukmana, 2013).

Omar, Abduh \& Sukmana (2012) states that though value based salam has been approved by Ibn Taymiyyah and the benefit of using this type of salam is that the arrangement ensures that the buyer is able to hedge against the price fluctuation of the future goods. They also state that value-based salam has been criticized for 
various reasons. For example, it has been said that since the quantity is not wellspecified at maturity, it violates the usual salam contract and it has been said that in essence, it is money for the money involved in value-based salam and indirectly it leads to riba. Al Suwailem has given responses to these two criticisms (Omar, Abduh \& Sukmana, 2012). He says that the quantity has to be identified at the beginning to avoid or eliminate the possibility of dispute. If the dispute is absent, the condition needs no be observed. The value of the commodity is determined (US\$ 11,000), so there will be no dispute as all variables are determined by the market.

With regard to the indirect way of riba, the value based salam is not riba, either in form or substance. At maturity, the buyer receives goods and not money. This arrangement differs from Murabahah. In Murabahah, banks buy spots contracts and sell to the customer with the deferred payment from the customer. In this value-based salam transaction, the bank buys a deferred product from the seller (farmer) and sells the spot contract to the buyer or customer. Essentially, Murabahah and value-based salam are equivalent; the only difference is the sequence of the steps. Value-based salam also differs from controversial contracts, such as 'inah and tawarruq. In both of these contracts, the commodity used can be generated without limit. It means that the same commodity can be reused many times. Hence a huge debt can be created with an upper limit. Nevertheless, it is impossible for that commodity to be reused in the salam contract as well as the value based salam contract. This is because, at the time when goods or commodities are delivered, the debt will no longer exist.

\section{Steps needed to execute Modified Reverse Salam Product}

According to Mahaini (2017), there are two main steps to execute the Product:

1) Subscribing to Value-based salam product - contract initiation phase $(\mathrm{t}=0)$ : during this step, the following should be performed:

a) The customer deposits cash entering into a value-based salam Product with the bank to buy a determined value of $\mathrm{CPO}$ to be delivered after a specified amount of time.

b) The bank grants the customer access to Bursa Suq Assalam Platform (BSAP) to be freely accessed through the customer's online banking account to create an avenue to perform the sale transaction upon maturity.

E.g: Customer deposits RM $97.5 \mathrm{k}$ (investment amount) for a RM $100 \mathrm{k}$ worth of $\mathrm{CPO}$ after 90 days. 
2) At maturity: $(\mathrm{t}=\mathrm{m})$ :

a) The bank buys CPO worth of RM $100 \mathrm{k}$ from Bursa Suq Assalam Platform (BSAP) and takes constructive possession of it.

b) The bank constructively delivers the commodity through the Platform System (BSAP) to the customer.

c) The customer will be immediately notified when the commodity is delivered to him/her (via email and SMS), and once the possession is taken, he/she has the freedom to perform any sale transaction via the online banking system.

d) The profit for the customer is the difference between the deposited buying price (RM $97.5 \mathrm{k}$ ) and the selling price for which the commodity is sold to an independent third party through the Platform (RM $100 \mathrm{k}$ ).

3) When the possession is taken by the customer, he/she has three different options to exercise:

a) At the time of product subscription stage, the customer will have to activate his/her online platform to authorize the selling of the commodity immediately upon taking possession of commodity to avoid risks associated with the ownership.

b) If at the time of the possession, if the customer has not chosen option a), he/she has the option to sell the commodity manually through the Platform by clicking a sell button through his/her online account. However; following are the risks associated with this option:

i) The customer must be properly informed with the possible gains/ losses due to CPO market price fluctuations.

ii) The customer must pay an agreed-upon daily storage fee to the Islamic bank, which in-turn shall pay it to the warehouse owner (CPO broker).

c) The customer also has the option to take actual physical possession of the commodity, as this is a real sale. However; if this option is exercised:

i) The customer shall specify the appropriate location for the commodity to be delivered to.

ii) The customer shall pay transportation fee(s) and any storage fee(s) if applicable. 


\section{Modus Operandi}

Figure 2

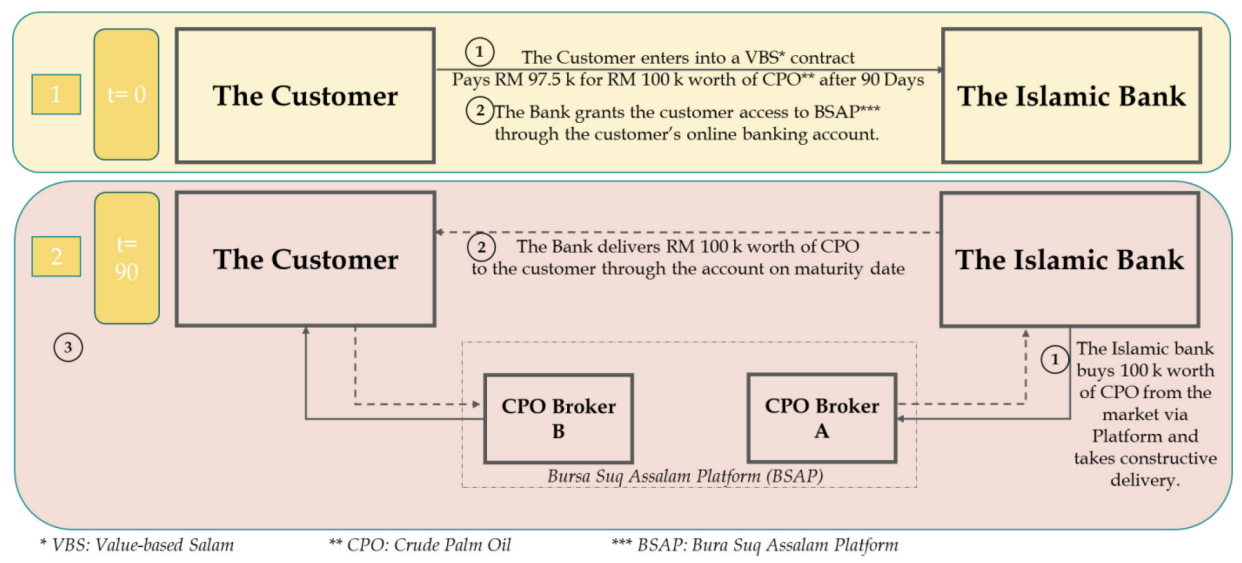

Source: Mahaini (2016)

\section{Bursa Suq Assalam Platform (BSAP)}

Bursa Suq Assalam Platform or BSAP is a special commodity trading platform that shall be supervised by a regulatory authority (Mahaini, 2017). The most appropriate regulatory authority to supervise the platform could be either the Central Banks or Securities Commissions/Capital Market Regulatory Authorities, depending on the jurisdiction in which it is introduced. This platform needs fintech solutions to enhance its infrastructure, and the accessibility to the platform shall not only be given to the financial institutions, but it must also be given to the individuals or retail customers too for wider coverage of financial inclusion.

The most initial phase of setting up of BSAP as a domestic platform is to choose the most appropriate underlying asset that could be used in the transaction. Depending on the jurisdiction, the commodity will differ as the commodity used in the trade shall be a commodity that shall be easily available in the jurisdictions in which BSAP is operated. The paramount consideration that shall be given in choosing the commodity from a social perspective is to choose a commodity that is produced by poor and needy. For example in a jurisdiction where the fisherman is the targetted population, fish processed durably could be the suitable commodity used while in jurisdictions where farmers are the targetted population, farming products could be the suitable commodity used. Likewise, oil and other suitable commodities for a salam transaction can be chosen. Since CPO is used in illustrating the product in this research, in the discussions, $\mathrm{CPO}$ will be used as a commodity. 
The customers buying the commodity in BSAP shall have the option to either sell the commodity after the constructive delivery or to have a physical delivery. This is to ensure that a real trade will take place between the parties in the platform, and there is no room for hilah (legal device). The procedures in buying and selling of the commodity in the platform will be derived from the fintech solutions available in the respective jurisdictions, including the availability of the internet and its speed.

The main reason why BSAP is required to be established is to ensure the transactions involved in the offering of the product is offered swiftly and effectively without the involvement of cumbersome procedures where physical running from one office to another by the customer is avoided. The establishment of a sophisticated BSAP will provide a one-stop solution for the offering of whole product from a staff at the bank while sitting near a computer or if mobile technology is integrated, a customer at a remotely accessible location will be able to perform the transaction via his mobile without human involvement at all making the product attractive for a better financial inclusion landscape.

The most important point to be understood here is that establishment of BSAP is an integral part for the successful implementation of the proposed product as the effective and convenient offering of the product will only be possible by the integration of BSAP to it.

\section{Conclusion}

Financial inclusion in islamic finance is an area that needs focus to narrow financial exclusion at a global level. The way to achieve this suggested in this research is by introducing an innovative sharia compliant product that will assist the mobilizing fixed deposits in jurisdictions with limited sharia compliant investment avenues to promote financial inclusion. However, the success of the product will depend on customization of it to the local circumstance of the jurisdiction in which it is implemented.

\section{References}

Al- Masri, Rafic Yunus. 2003. "Market price of Salam on the date of delivery: Is it permissible?” J.KAU: Islamic Econ 16(2): 29-32.

Al Suwailem, S. 2006. Hedging in Islamic finance. Jeddah: Islamic Development Bank.

Al Zaabi, Obaid Sai. 2010. "Salam contract in Islamic law: A Survey." Review of Islamic Economics 14(2): 91-122.

Al-Zuhayli, Wahbah. 2007. Financial transactions in Islamic jurisprudence. Mohamoud A. el-Gamal. trans. Beirut: Dar al-fikir al-Mauaser. 
Dchieche, Amina. \& Rajae Aboulaich. 2016. "Pricing Bounded Value Based Salam." Journal of Applied Economics Sciences 11(3): 41-49.

Banerjee, Abhijit \& Andrew F. Newman. 1993. "Occupational Choice and The Process of Development." Journal of Political Economy 101(2): 274-298.

Bank Negara Malaysia. Financial sector blueprint 2011-2020, Retrieved December 31, 2016 from <http://www.bnm.gov.my/files/publication/fsbp/en/ BNM_ FSBP_FULL_en.pdf>

Beck, Thorsten, \& Asli Demirguc-Kunt. 2008. "Access to Finance: An Unfinished Agenda." The World Bank Economic Review 22(3): 383-396.

Dchieche, Amina. \& Rajae Aboulaich. 2016. "New Approach to Model Salam Contract for Profit and Loss Sharing." International Journal of Applied Engineering Research 11(2): 909-916.

Dusuki, A.W. 2007. "Commodity Murabahah Programme (CMP): An Innovative Approach to Liquidity Management." Journal of Islamic Economics, Banking and Finance 3(1): 1-23.

Mahaini, Mohammad Ghaith. 2016. Modified reverse Salam, an innovative solution for Islamic liquidity management. Retrieved February 7, 2017 from < http:// www.islamicfinancenews.com/authors/mohammad-ghaith-mahaini>

Galor, Oded \& Joseph Zeira. 1993. "Income Distribution and Macroeconomics." The Review of Economic Studies 60(1): 35-52.

Islamic Finance News, IFN Guide 2017. Retrieved February 7, 2017 from http:// www.islamicfinancenews.com/content/ifn-annual-guide-2017.

Omar, Mohd. Azmi, Muhamad Abduh \& Raditya Sukmana. 2012. Fundamentals of Islamic money and capital markets. Hoboken, N.J.: John Wiley \& Sons.

Pearce, Douglas. 2010. Financial inclusion in the Middle East and North Africa: Analysis and roadmap recommendations. Washington DC: The World Bank.

Saleem, Muhammad Yusuf, Mohammad Ghaith Mahaini \& Hussain Kureshi. 2014. "Reverse Salam as an Innovative Instrument for Investment Accounts." International Journal of Islamic Finance 6(1): 183-193.

The World Bank Group. 2014. The Global Findex Database 2014: Measuring Financial Inclusion around the World, (Policy Research Working Paper 7255)

Umar, Muhammad Abd al-Halim. 1991. Al-Itar, al-Shari wa' Iqtisadi wa' muhasabi libay al-salam (Legitimate, economic, and accounting framework of salam contract). Jeddah: Islamic Institute for Research and Training, Islamic Development Bank. Usmani, M. T. 2004. An introduction to Islamic finance. Karachi: Maktaba Ma’ariful Quran. 